\title{
INTRODUCTION TO THE PERIGLACIAL ENVIRONMENT IN FINLAND
}

\author{
MATTI SEPPÄLÄ
}

MATTI SEPPÄLÄ, 1997: Introduction to the periglacial environment in Finland. Bull. Geol. Soc. Finland 69, Part 1-2, 73-86.

An overview is presented of the periglacial characteristics of climate and landforms in Finland. Mean annual air temperature (MAAT) in Finland ranges from +5.5 to $-3^{\circ} \mathrm{C}$, and frost sums in most parts of the country are large enough for active seasonal frost. Local conditions are more important in the formation of frost features than the overly general mean values of air temperature, however. Snow depth is the critical factor for most frost features, and permafrost is observed only in northern parts of the country, where thin snow cover supports frost activity. A brief description of features indicating frost activity is presented. Palsas, pounus, and string mires are peat landforms designed by frost. Fell slopes exhibit additional features of talus, slush flows and gelifluction lobes and terraces. Frost heave and contraction cracking are characteristic features occuring even in fields in southern Finland. Active frost-sorted patterned grounds are common in northern Finland, especially at the bottoms of shallow, seasonally dry ponds. Ground water close to the surface is essential for the formation of most frost features. Special forms of both aeolian and fluvial activity are part of the periglacial environment in Finland. Snow drift and deflation of sand surfaces formed by glaciofluvial processes during deglaciation are part of the periglacial environment in Lapland. Drastic spring floods with ice dams formed in river channels are typical for northern rivers. Proposals for further studies are made at the end of the paper.

Keywords: periglacial environment, climate, frost section, permafrost, periglacial features, palsas, frost heaving, patterned ground, eolian features, Holocene, Lapland, Finland.

Matti Seppälä, Physical Geography Laboratory, PO Box 9 (Siltavuorenpenger 20A), FIN-00014 Helsinki University, Finland. matti.seppala@helsinki.fi 


\section{INTRODUCTION}

The term periglacial was first proposed by von Lozinski (1909) to describe frost weathering conditions in the Carpathian mountains. Later he introduced the term periglacial zone to describe the climatic and geomorphological conditions of tundra outside the Pleistocene ice sheet and glaciers (Lozinski 1912).

In modern usage, the term periglacial covers a much broader range of cold conditions with no any necessary connection to glaciers in either space or time. According to the Glossary of permafrost and related ground-ice terms (1988: 63), periglacial means "the conditions, processes and landforms associated with cold, nonglacial environments".

The diagnostic criterion for periglacial designation is intense frost action, which may be associated with either seasonal frost or perennial frost. Periglacial processes are possible in environments where the air temperature stays below freezing for a considerable time and where frost affects soil forms and creates distinctive geomorphic features.

Permafrost means that the temperature in soil or bedrock remains continuously at or below $0^{\circ} \mathrm{C}$ for at least two years (Glossary of permafrost ... 1988: 63). Seasonal temperature fluctuations above and below zero take place in the active layer above the perennially frozen ground which means that the active layer is subject to annual thawing and freezing. That, in turn, initiates a variety of geomorphic processes typical of the periglacial environment. The depth of the active layer ranges from a few decimeters to metres depending on local climatic conditions and soil characteristics.

Characteristic geomorphic processes (see e.g. Tricart 1970; Washburn 1979; Thorn 1992; French 1996: 7) in periglacial environments are

- permafrost formation with ice segregation

- thermal contraction of ground

- creep of ice-rich soil and the thawing features of frozen ground

- frost shattering of rocks and cracking of soils
- frost heave, stone tilting, mass displacement and particle size sorting

- soil creep and churning

- rapid mass movements such as rockfalls, slumps and failures and slow solifluction of water-saturated soil and gelifluction

- fluvial processes of ice wasting and snowmelt origin, and fluvial processes associated with ice dams, and quick-rising spring floods

- strong aeolian activity causing sand, silt, snow and organic debris to drift with intense deflation and accumulation because of lack of vegetation.

My primary aim in this presentation is to provide an overview of the periglacial characteristics of Finland: the distribution of frost features and the environmental conditions required for frost formation. Earlier review articles covering periglacial morphological studies in Finland can be found in the literature (e.g. Okko 1954; Aartolahti 1980; Seppälä; 1982c; 1987). There is no need to repeat all that has been written earlier and I offer instead some examples of recent studies in the field, suggest a few needs, and briefly formulate new directions for research.

\section{FROST AND CLIMATE IN FINLAND}

The total length of Finland from south to north is about $1160 \mathrm{~km}$, a distance great enough to offer a wide variety of climate and frost conditions. The Arctic Circle cuts across the country, and close to that latitude the mean annual air temperature (MAAT) is $0^{\circ} \mathrm{C}$. In SW Finland MAAT is above $+5.5^{\circ} \mathrm{C}$, in Helsinki it is about $+5^{\circ} \mathrm{C}$ and in the NW corner about $-3^{\circ} \mathrm{C}$ (Atlas of Finland 1988: 131: 5m) (Fig. 1A). The highest mean frost sums (freeze index) for October-April are above $2000 \mathrm{~d}^{\circ} \mathrm{C}$ (Atlas of Finland 1988: 131: 14e) (Fig. 2B). However, if we study the values year by year, for Kevo meteorological station $\left(69^{\circ} 45^{\prime} \mathrm{N}\right)$, for example, the minumum may be about 1500 and maximum more than $2700 \mathrm{~d}^{\circ} \mathrm{C}$ (Seppälä \& Hassinen 1997). The high freeze 

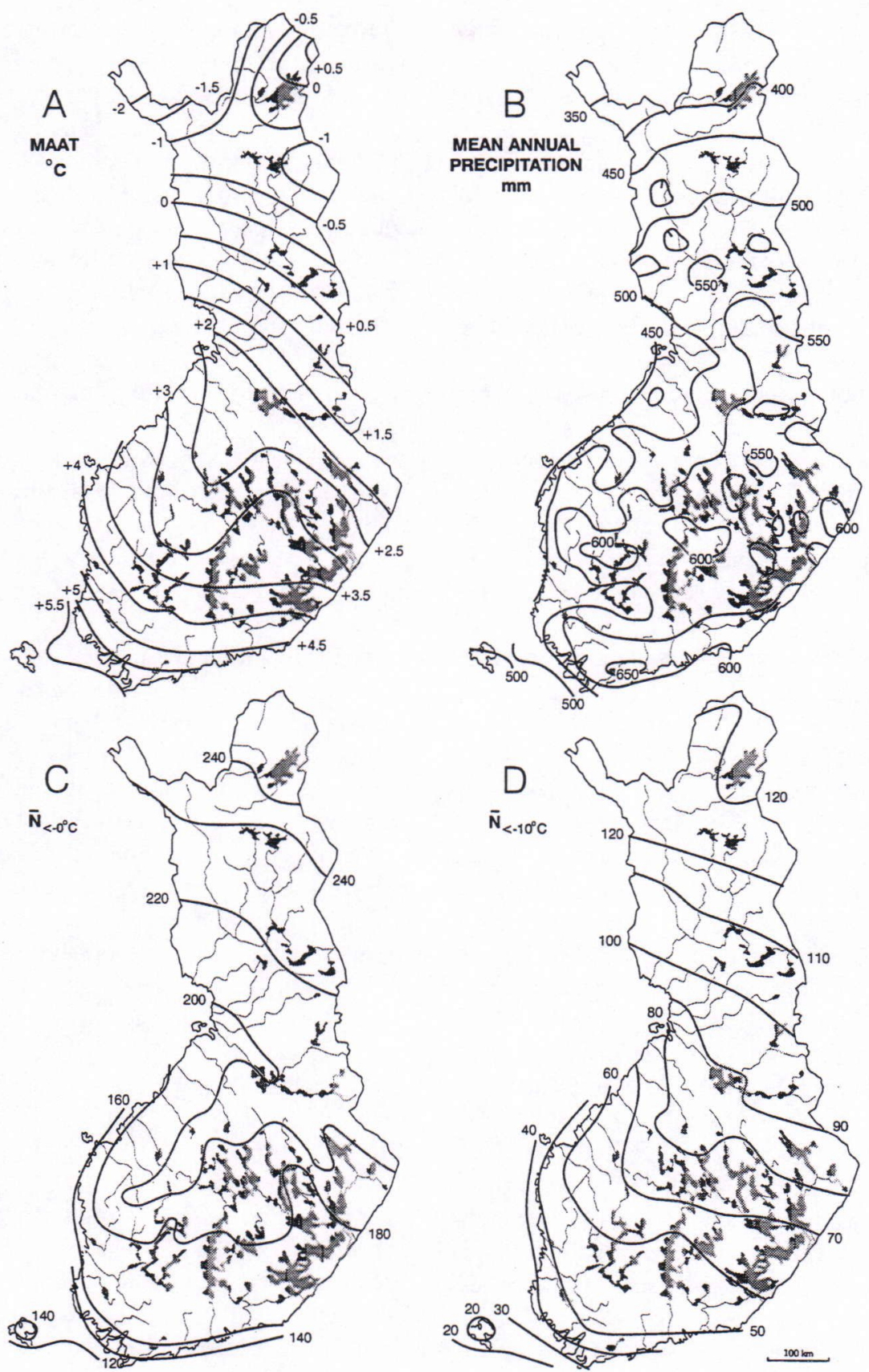

Fig. 1. A. Mean annual air temperature (MAAT) in Finland in the period 1931-1960 (Atlas of Finland 1987, 131: $5 \mathrm{~m}$ ). B. Mean annual precipitation in the period 1931-1960 (Atlas of Finland 1987, 131: 19m). C. Mean annual number of days with minimum temperature below $0^{\circ} \mathrm{C}$ in the period 1961-1975 (Atlas of Finland 1987, 131: 14a). D. Mean annual number of days with minimum temperature below $-10^{\circ} \mathrm{C}$ (Atlas of Finland 1987, 131: $14 b)$. 
index (=daily frost sums) may produce frost layers that remain unmelted for several years.

The number of frost days (=minimum temperature below $0^{\circ} \mathrm{C}$ ) ranges from 120 to about 260 days from the SW coast of Finland to Enontekiö (Fig. 1C), and the number of days with minimum temperatures below $-10^{\circ} \mathrm{C}$ varies from 20 to about 130 days respectively (Fig. 1D). This means that conditions are favourable for relatively deep frost formation in most part of Finland.

Temperature values expressed as MAAT can give us only a very general idea of the frost climate because many other factors control the frost formation. The important factor in frost formation is ground temperature, which the standard meteorological observations, made in a shelter $2 \mathrm{~m}$ above the surface, often do not include. The local frost forming conditions cannot be identified without detailed measurements (Seppälä \& Hassinen 1997). Snow depth is the critical factor for frost formation in Lapland (Seppälä 1990; 1994).

The mean maximum snow depth in SW Finland is about $34 \mathrm{~cm}$. The depth increases from the coast inland and from south to north, so that on the eastern border it reaches a mean value of $80 \mathrm{~cm}$ or more (Fig. 2A) and in the NW corner, in forested areas, over $100 \mathrm{~cm}$ (Atlas of Finland 1988: 131: 21a). These values tell nothing about the snow depth in fell regions, however. Above the timber line and on open mires the snow cover tends to be very thin, often less than $5 \mathrm{~cm}$ (Clark et al 1985), and this provides the cold an opportunity to penetrate deep into the ground.

In northernmost Finland the snow remains on the ground from the beginning of October to the end of May. The average precipitation ranges from about $650 \mathrm{~mm}$ in southern Finland to less than $350 \mathrm{~mm}$ in the north (Fig. 1B). The amount of annual precipitation received as snow is, respectively, about 30 per cent to 60 per cent (Atlas of Finland 1988: 131: 21i).

\section{FROST FORMATION}

The maximum depth of frost penetration in till at sites cleared of snow ranges from less than $120 \mathrm{~cm}$ along the SW coast more than $230 \mathrm{~cm}$ in central Enontekiö in Lapland (Soveri \& Varjo 1977: fig. 21; Atlas of Finland 1988: 131: 14f) (Fig. 2C). In some years the frost penetrates unusually deep in the ground without forming permafrost. For example, at Kevo meteorological station the mean monthly temperature in May 1971 at the depth of $2.9 \mathrm{~m}$ was $-1.77^{\circ} \mathrm{C}$ (Seppälä 1976: fig. 11).

In a study of the effects of frost on building constructions: water and sewage pipes in the ground Kaitera and Helenelund $(1947 ; 1948)$ concluded that the frost-free depth in till, gravel and sandy soils ranges from about $200 \mathrm{~cm}$ in the SW coastal region to more than $260 \mathrm{~cm}$ in northern Lapland (Fig. 2D).

The maximum soil frost season lasts about 8 months in northern Lapland and the longest frost-free season is about 8 months in the southern coastal area (Soveri \& Varjo 1977: fig. 24).

Permafrost is much more widely distributed in Finland than previously thought (King \& Seppälä $1987 ; 1988)$. A relatively detailed presentation of the distribution can be found in this volume (Seppälä, in press). Finland is located at the margin of the zone one of discontinuous permafrost with the southern limit north of the $68^{\circ} \mathrm{N}$ latitude. The main part of the country belongs to the region of seasonal frost.

\section{FEATURES INDICATING FROST AC- TIVITY}

Although it is possible to study periglaciation as a climatic problem, our tools are inadequate because present meteorological observations and mean values do not give us the information we need from ground level nor from all sites where periglacial features appear. As an alternative we may consider the various features associated with frost and draw conclusions about the special factors affecting periglacial processes, which are complex events controlled not only by weather but also by relief, soil moisture, soil and vege- 

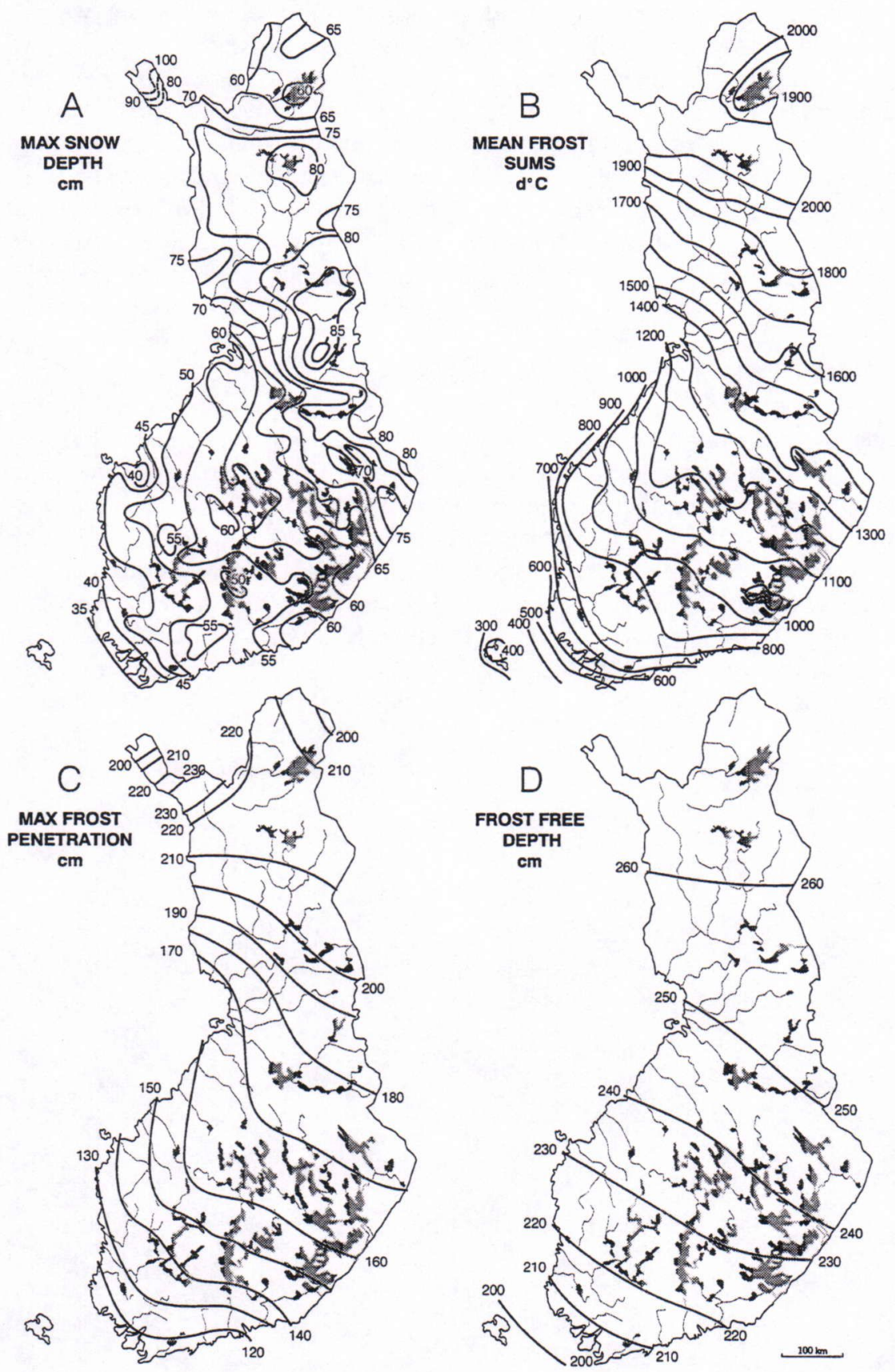

Fig. 2. A. Mean of the maximum snow depth in forests in Finland in 1921-1960 (Atlas of Finland 1987, 131: 21a). B. Mean frost sums (freeze index) of the period October-April in 1961-1980 (Atlas of Finland 1987, 131: 14e). C. Mean of maximum frost penetration in till at sites cleared of snow, 1955-1975 (Atlas of Finland 1987, 131: 14f). D. Frost-free depth of soils (Kaitera \& Helenelund 1948, fig. 7). 
tation characteristics and many other factors. Climatological studies of regions exhibiting frost features give us a restricted framework in small scale for large areas, whereas when we try to interpret the existence of certain periglacial feature we are working in large scale in a special area. This needs to be kept in mind when relict features are used to draw conclusions about palaeoclimate.

\section{PEATLAND MORPHOLOGY}

Palsas are the most characteristic frost feature in the zone of discontinuous permafrost (e.g. Seppälä 1988), typically being found in valleys or basins with relatively thick peat formation. Peat is an essential material for the survival of the frozen core of palsas. Thin snow cover, in turn, is the critical factor for initiation of the permafrost core (Seppälä 1982a; 1986; 1990) and snow thickness controls the growth in size of the palsa (Seppälä 1994).
In the same environment where palsas are found there are likely to be other periglacial features which require for their formation not permafrost but deep seasonal frost. Large areas of northern Lapland are characterized by small peat and earth mounds (pounus) (Fig. 3), which have a seasonal frozen core that may remain intact for years. Detailed year-round temperature measurements with high frequency have shown that very strong temperature inversion is possible on the snow surface (Tabuchi \& Seppälä 1997) and this could explain the deep frost formation in pounus, where snow cover on the top of the mounds is very thin.

South of the palsa zone the mires typically feature string stripes on their surfaces, and frost seems to collaborate in their formation by heaving the peat. Snow depth is thin on the strings and thick on the pools in between, and this controls the frost formation (Koutaniemi \& Seppälä 1986).

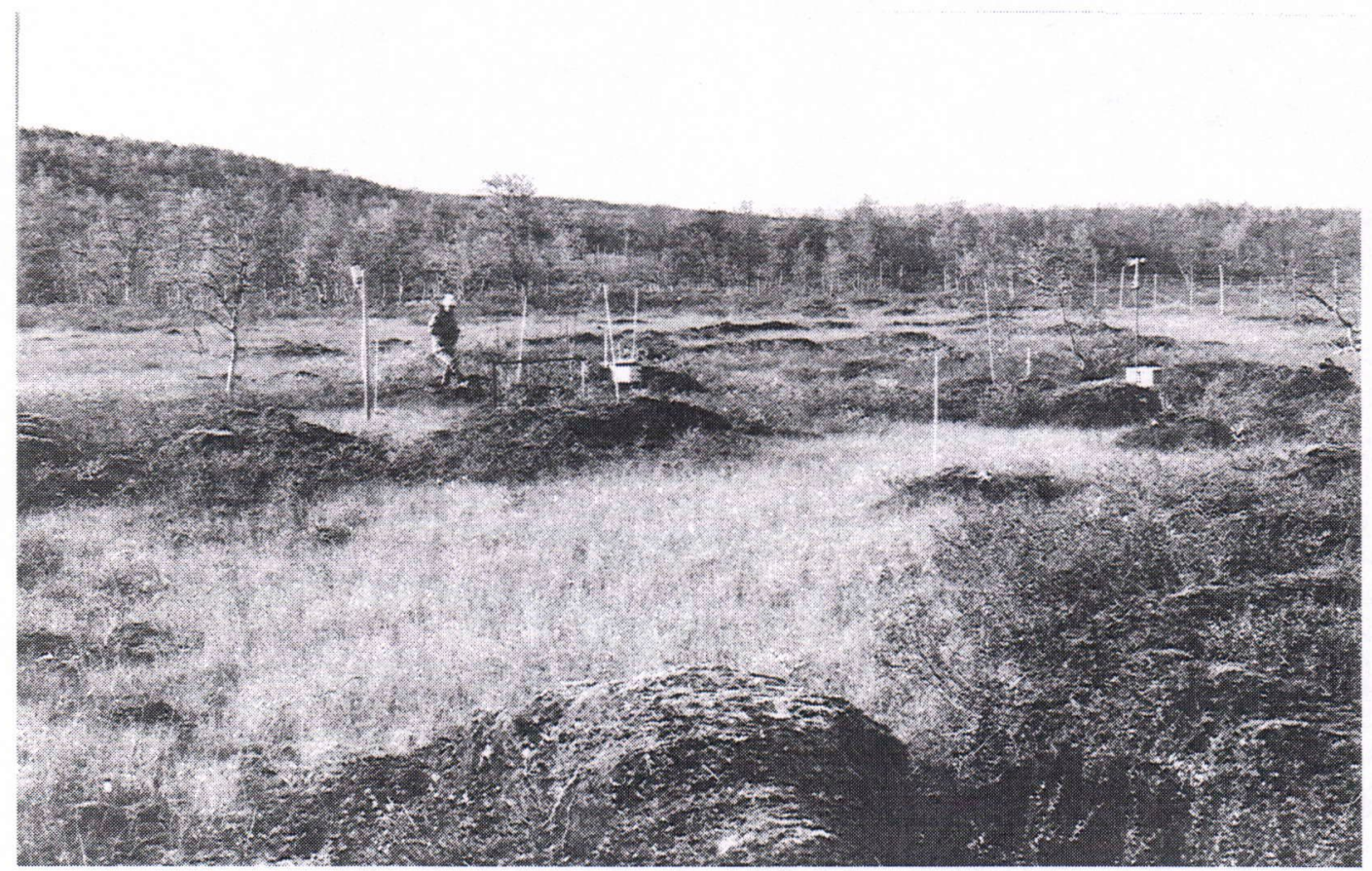

Fig. 3. Peat pounu field (=pounikko) instrumented for frost measurements at Vaisjeäggi mire in Utsjoki. Photographs by the author. 


\section{SLOPE PROCESSES}

Both rapid and slow mass movements take place on slopes above the timber line. Well developed talus features are common at the bottom of steep slopes in the high fell region.

Slush flows, which are avalanches of watersaturated snow that form chaotic deposits below waterfalls have recently attracted the attention of investigators in Finnish Lapland (Clark \& Seppälä 1988). Their occurence now needs to be studied in more detail. We know already that slush flows occur when the air temperature rises quickly in late winter and the warm weather is accompanied by heavy rain.

Slow mass movements give rise to gelifluction lobes and terraces on the slopes of fells (Kejonen 1979; Seppälä 1982c; 1993). The rate of the surface movement is of considerable interest. On the western slope of Saana fell near Kilpisjärvi, the average annual rate was found to be $20 \mathrm{~mm}$ (Seppälä 1979). Similar measure- ments are now needed on other slopes, with different dips and aspects.

\section{FROST HEAVE, FROST SORTING AND PATTERNED GROUND}

Frost heave takes place everywhere in the region of seasonal frost. Measurements in northern Finland have shown that, in places with silt soils and suitable ground water conditions, roads may sometimes heave as much as $50 \mathrm{~cm}$ (Seppälä 1987). Frost heave also rises big boulders to the surface (Fig. 4) in a process that seems to continue year after year until the boulders no longer are in contact with the fine sediments underneath. Running meltwater and ground water wash the fines away from stone pits and larger boulder depressions (Seppälä 1982c, 1987), which in southern Finland may be relict features 10 to 20,000 square metres in diameter (Söderman 1982).

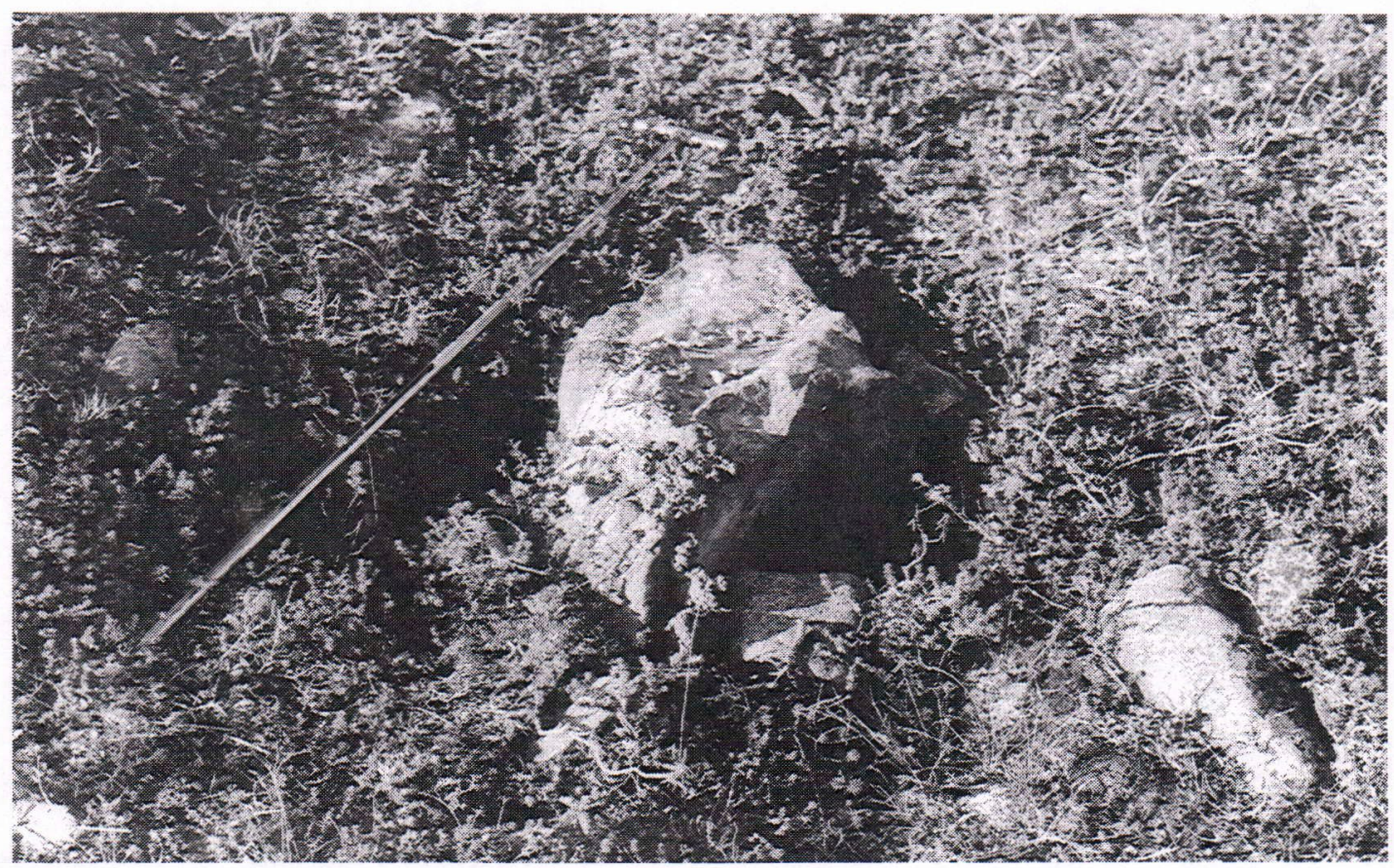

Fig. 4. Fresh frost heaved block at Skallovarri, Utsjoki. The stick used as scale is $1 \mathrm{~m}$ long. 
Only at certain very active heave sites does frost sorting and patterned ground formation take place. Frost sorting, and to lesser degree patterned ground formation, take place in shallow ponds with silty till or gravel bottoms. These ponds are often seasonal, which means that they are filled with water in spring and early summer but are dry for most of the rest of the year, and the ground water table is close to the surface during the freezing. We do not know much about the sorting process in general, and that should be studied. Lapland offers some excellent sites for a follow-up type investigation of sorted stone polygons.

The most active periglacial features in southern Finland are frost heave of stones and boulders on fields and mudboils on roads cutting across silty deposits. Occasionally, surfaces when the temperature drops fast and the earth is free of snow, frost causes contraction cracking of fine sand and silt (Aartolahti 1970).

Contraction cracking by frost causes frostcrack polygons in sand dunes in Lapland (Aartolahti 1972; Seppälä 1982c). On vegetationcovered deflation surfaces spanning sand dunes, the polygons are bounded by furrow-like depressions in the ground with a 5 to $15 \mathrm{~cm}$ deep open fissure in the middle of them. The polygons are irregular in shape, and their sides vary in legth from 1 to $12 \mathrm{~m}$ (Seppälä 1982c). It is essential for the formation of these polygons that the ground water table lies close to the surface.

Contraction crack polygons of a different type are found at the bottoms of seasonal shallow ponds in NW Enontekiö (Fig. 5). There silty till with scattered stones forms angular polygons with diameters ranging from 0.5 to $2 \mathrm{~m}$. No sorting has been observed on these surfaces. The role of frost or desiccation in the formation of these patterned grounds is unknown.

One more type of patterned ground, which has nothing to do with permafrost, is the sandwedge polygons found in some blow-outs in Lapland (Seppälä 1982c; 1987) (Fig. 6). Stratified glaciofluvial silt, which deflation has ex-

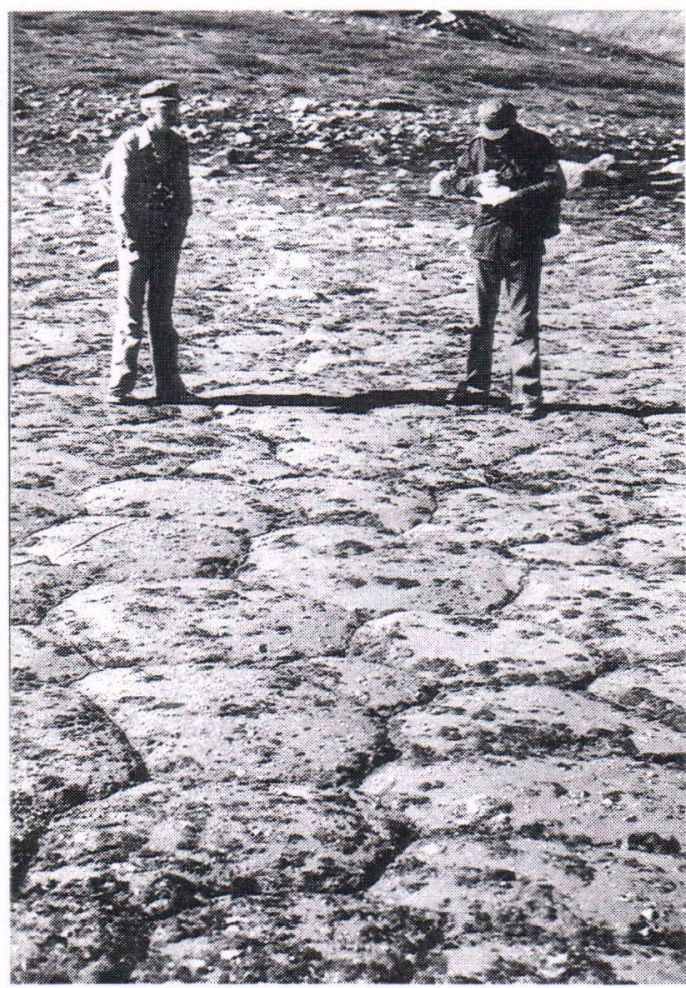

Fig. 5. Unsorted patterned ground at the bottom of a dried-up pond at the fell Pikku-Malla, Kilpisjärvi.

posed, has been dissected by fissures filled with aeolian sand. The wedges are between 35 and $50 \mathrm{~cm}$ deep and their width at the surface varies from 30 to $60 \mathrm{~cm}$ (Fig. 7). Sand-wedge polygons are from 2 to $4 \mathrm{~m}$ in diameter. Seasonal frost may open cracks in the silt and, during the summer, aeolian sand transported on the surface of the blow-out fills the crack. During winter the silt is deeply frozen, but the sand wedge itself is dry (Seppälä 1982c; 1987). Also in this case, detailed measurements in the field could throw light on the process. In the formation of these sand wedges, soil moisture probably does not play any more important role than to support deflation though cryoturbation features associated with changes in the ground water table are common in this region (van Vliet-Lanoë et al. 1993). 


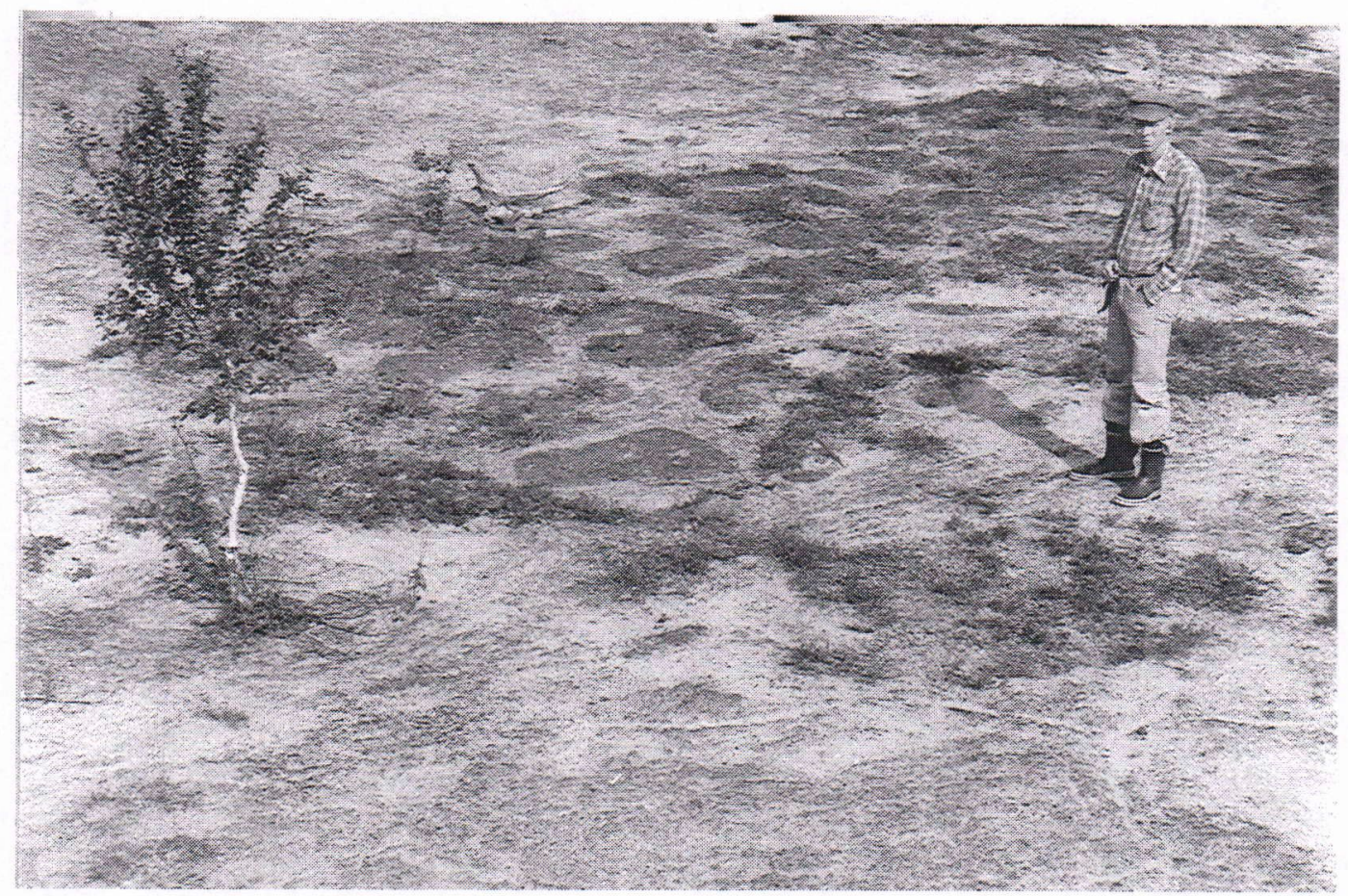

Fig. 6. Sand-wedge polygons in a blow-out at Hietatievat, eastern Enontekiö.

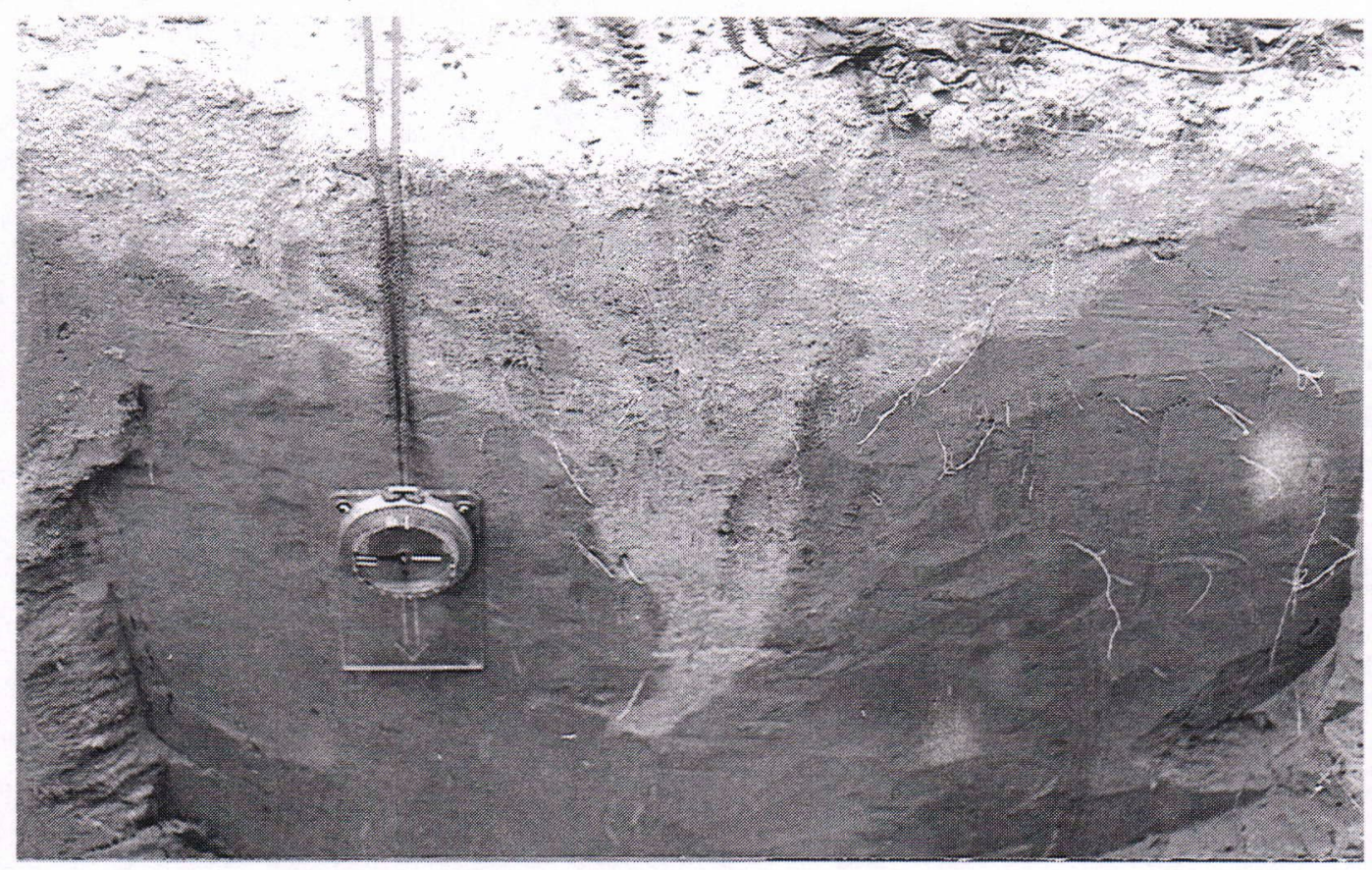

Fig. 7. Cross-section of a sand-wedge at Hietatievat. The wedge formed of aeolian sand has penetrated into stratified glaciolacustrine silt. 


\section{AEOLIAN ACTIVITY}

Wind plays a fundamental role in the periglacial environment where the vegetation cover is scarce due to cold (Fig. 8). Although aeolian activity is not directly related to frost, such typical aeolian features as sand dunes, deflation basins, cover sands, loess, ventifacts and other wind formed rock surfaces are part of the periglacial environment. In Finnish Lapland we find some small active sand dunes and a lot of blow-outs (Fig. 9), and much redeposited aeolian and glaciofluvial sand (Seppälä 1995). Change in the ground water table would seem to be a basic factor affecting the aeolian processes in Lapland.

It has been pointed out several times that wind is important for deep frost formation because while causing the snow drift it erodes the insulating snow cover and deposits it elsewhere (Seppälä 1982a; 1986; 1988; 1990; 1994). The snow accumulation characteristic of periglacial environment means that the aeolian activity differs radically from the activity in warm desert re- gions. For most part of the year the periglacial environment is a "white desert" without liquid water on the ground surface, but once the snow melts moisture is everywhere.

\section{FLUVIAL ACTIVITY}

Rivers in northern Finland should be classified as subarctic rivers with special chararcteristics typical for periglacial environment. In natural conditions the spring floods are drastic. Often ice dams form and above the dam the water level rises ten or more metres above normal. For most part of the year the rivers are ice covered and drainage of the land is limited. In summer many of the small creeks dry up. Very few studies have looked at the relation between frost and fluvial activity (Koutaniemi 1984; 1987; Threlfall 1987).

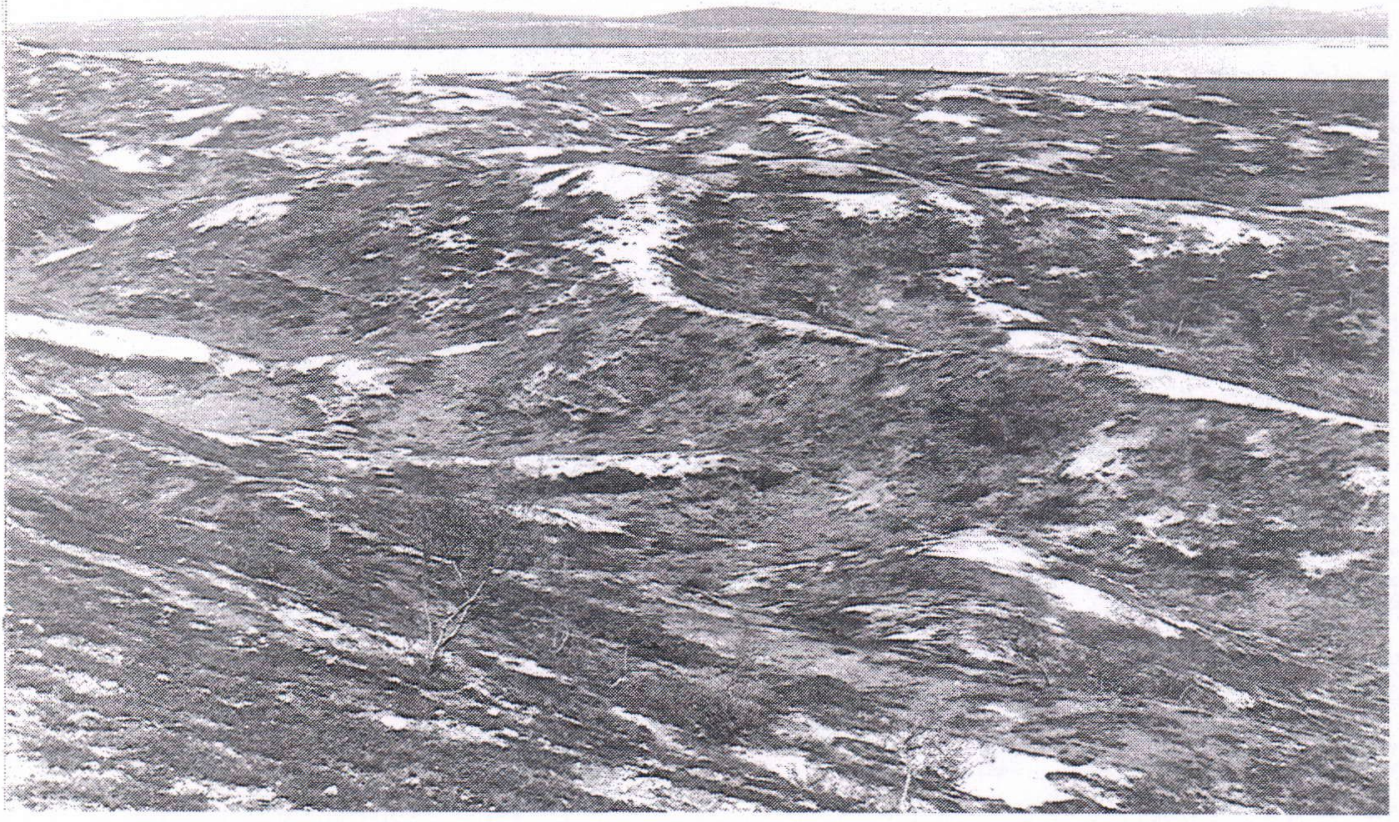

Fig. 8. Esker landscape with many blow-outs (white areas) at Lake Pöyrisjärvi (in the background), Enontekiö. 




Fig. 9. An esker surface with large blow-out at Peltoaivi, Utsjoki. The landscape is still largely covered in snow at the end of April.

\section{SOME PROPOSALS FOR FINNISH PERIGLACIAL STUDIES}

French (1987) and Thorn (1992) have described current research and forecast future trends for periglacial studies in North America. While many of their suggestions are also relevant for Finland we also have some nationally important tasks.

Detailed mapping and inventory of periglacial phenomena in Finland has not been completed. Geomorphic mapping with the aid of aerial photographs should be initiated in key regions in Lapland. Although we have scattered information for a few small areas, the picture as a whole remains very deficient. The mapping requires many field controls and these should increase our knowledge substantially.

A active layer measurements have been carried out on several palsas in Finnish Lapland over a period of more than 20 years (Seppälä 1976b; 1982; 1983). These measurements need to be continued, because the active layer reacts fastest to any changes in climatic conditions (cf. Pissart 1990).

Temperature monitoring should be directed more widely to frost features. This could bring to light many new observations, helpful in the interpretation of the frost processes. Temperature recordings in deep drill holes on fell summits should be started immediately to collect the reference information for temperature fluctuations.

Soil moisture measurements should be organized, even though this is a difficult task in winter. Movement of ground water in the pores of frozen ground is a key factor for the understanding of frost features.

The stratigraphy of seasonal frost and permafrost in Lapland is a much neglected field of research. Water content of different features should be studied in detail.

Because these studies have important applications, collaboration between all groups an interest in ground frost should be promoted and strengthened. We already have a national chapter of the International Permafrost Association 
(IPA), which brings together botanists, cartographers, engineers, geologists, geomorphologists, geophysisists, hydrologists and meteorologists. Although few concrete joint projects have yet been established, the needs are many. For example, we need to be prepared when exploitation of the Barents Sea gas resources begins. Knowledge of frost conditions in Finland will then be of great value. It is my hope that this meeting will move us towards some of these opportunities.
ACKNOWLEDGEMENTS: I would like to express my gratitude to the national INQUA Committee, which organized this symposium and especially to Dr. Marjatta Koivisto who cheerfully bore the heaviest load in taking care of the practical arrangements for the meeting. Mrs Kathleen Ahonen kindly revised the English of this manuscript. 


\section{REFERENCES}

Aartolahti, T. (1970) Fossil ice-wedge, tundra polygons and recent frost cracks in southern Finland. Annales Academiae Scientiarum Fennicae Ser. A III Geologica-Geographica 107, 1-26.

Aartolahti, T. (1972) Dyynien routahalkeamista ja routahalkeamapolygoneista. (Summary: Frost cracks and frost crack polygons on dunes in Finland.) Terra 84, 124-131.

Aartolahti, T. (1980) Periglasiaalisen morfologian tutkimus Suomessa. (Summary: The research of periglacial morphology in Finland.) Terra 92, 74-87.

Aartolahti, T. (1982) Den fossila periglaciala morfologin i södra Finland. Geografisk Tidsskrift 82, 74-77.

Atlas of Finland (1987) Folio 131 Climate. National Board of Survey and Geographical Society of Finland, Helsinki. 31 p.

Clark, M.J. and Seppälä, M. (1988) Slushflows in a subarctic environment, Kilpisjärvi, Finnish Lapland. Arctic and Alpine Research 20, 97-105.

Clark, M.J., Gurnell, A.M., Milton, E.J., Seppälä, M. and Kyöstilä, M. (1985) Remotely-sensed vegetation classification as a snow depth indicator for hydrological analysis in sub-arctic Finland. Fennia 163, 195-216.

French, Hugh M. (1987) Periglacial geomorphology in North America: current research and future trends. Progress in Physical Geography 11, 533-551.

French, Hugh M. (1996) The periglacial environment. Second edition. Addison Wesley Longman Limited, Essex. 341 p.

Glossary of permafrost and related ground-ice terms. (1988) Permafrost subcommittee. Associate Committee on Geotechnical Research, National Research Council of Canada. Technical Memorandum 142, $156 \mathrm{p}$.

Kaitera, P. and Helenelund, K. $(1947+1948)$ Roudan syvyydestä ja sen vaikutuksesta rakennusperustusten sekä vesi- ja likavesijohtojen syvyyteen. (Summary: The depth of frost and its influence on depth of foundations and of water and sewage pipe lines.) Teknillinen Aikakauslehti 37, 390-395 and 38: 2-8, 40.

Kejonen, A. (1979) Vuotomaista Muotkatuntureiden alueella Pohjois-Lapissa. (Summary: On solifluction sediments in the Muotkatunturit area, northern Lapland.) Publications of the Department of Quaternary Geology, University of Turku 40, 1-43.

King, L. and Seppälä, M. (1987) Permafrost thickness and distribution in Finnish Lapland - Results of geoelectrical soundings. Polarforschung 57, 127147.

King, L. and Seppälä, M. (1988) Permafrost sites in Finnish Lapland and their environment. Occurrences de pergelisol en Lapponie Finlandaise. Permafrost Fifth International Conference, Proceedings $1,183-188$.

Koutaniemi, L. (1984) The role of ground frost, snow cover, ice break-up and flooding in the fluvial processes of the Oulanka river, Finland. Fennia 162: 127-161.

Koutaniemi, L. (1987) Characteristics of a high-latitude fluvial environment: the river Oulankajoki, NE Finland. In: V.Gardiner (ed.): International Geomorphology 1986 Part 1. John Wiley \& Sons, Chichester, 571-574.

Koutaniemi, L. and Seppälä, M. (1986) Aapasuon routaa säätelevät tekijät - esimerkkitapaus Kuusamosta. (Summary: Factors controlling ground frost on an aapa mire in Kuusamo, Finland.) Terra 98, 60-67.

Lozinski, W. (1909) Über die mechanische Verwitterung der Sandsteine im gemässigten Klima. Bulletin International de l'Académie des Sciences de Cracovie, Classe des Sciences Mathématiques et Naturelles 1, 1-25.

Lozinski, W. von (1912) Die periglaziale Fazies der mechanischen Verwitterung. Congrès Géologique International, Compte Rendu de la XI:e Session, Stockholm 1910, 1039-1053.

Okko, V. (1954) Periglasiaalisesta morfologiasta Suomessa. (Summary: Periglacial morphology in Finland.) Terra 66, 54-57.

Pissart, A. (1990) Advances in periglacial geomorphology. Zeitschrift für Geomorphologie N.F. Supplement-Band 79, 119-131.

Seppälä, M. (1976a) Periglacial character of the climate of the Kevo region (Finnish Lapland) on the basis of meteorological observations 1962-71. Reports from the Kevo Subarctic Research Station 13, 1-11.

Seppälä, M. (1976b) Seasonal thawing of a palsa at Enontekiö, Finnish Lapland, in 1974. Biuletyn Peryglacjalny 26, 17-24.

Seppälä, M. (1979) A new technique to measure the rate of mass movement on slopes. Studia Geomorphologica Carpatho-Balcanica 13, 221-224.

Seppälä, M. (1982a) An experimental study of the formation of palsas. Proceedings 4th Canadian Permafrost Conference, 36-42. 
Seppälä, M. (1982b) Palsarnas periodiska avsmältning i Finska Lappland. Geografisk Tidsskrift 82, 3944.

Seppälä, M. (1982c) Present-day periglacial phenomena in northern Finland. Biuletyn Peryglacjalny 29, 231-243.

Seppälä, M. (1983) Seasonal thawing of palsas in Finnish Lapland. Proceedings Fourth International Permafrost Conference, National Academy Press, Washington D.C. 1127-1132.

Seppälä, M. (1986) The origin of palsas. Geografiska Annaler 68A, 141-147.

Seppälä, M. (1987) Periglacial phenomena of northern Fennoscandia. In: John Boardman (ed.): Periglacial processes and landforms in Britain and Ireland. Cambridge University Press, Cambridge, 45-55.

Seppälä, M. (1988) Palsas and related forms. In: M.J. Clark (ed.): Advances in periglacial geomorphology. John Wiley, Chichester, 247-278.

Seppälä, M. (1990) Depth of snow and frost on a palsa mire, Finnish Lapland. Geografiska Annaler 72A, 191-201.

Seppälä, M. (1993) Solifluction in northern Finland: past and present. In: Burkhard Frenzel: Solifluction and climate variation in the Holocene. Gustav Fischer Verlag, Stuttgart. Paläoklimaforschung 11, 59-70.

Seppälä, M. (1994) Snow depth controls palsa growth. Permafrost and Periglacial Processes 5, 283-288.

Seppälä, M. (1995) Deflation and redeposition of sand dunes in Finnish Lapland. Quaternary Science Reviews 14, 799-809.

Seppälä, M. (in press). Distribution of permafrost in Finland. Bulletin of the Geological Society of Finland 69, Part 1-2, 00-00.

Seppälä, M. and Hassinen, S. (1997) Freeze-thaw indices in northernmost Fennoscandia according to meteorological observations, 1980-1191. In:
Sven Knutsson (ed.): Ground Freezing 97. Frost action in soils. Proceedings of the International Symposium on Ground Freezing and Frost Action in Soils, Luleå. Balkema, Rotterdam, 153-160.

Seppälä, M. and Koutaniemi, L. (1985) Formation of a string and pool topography as expressed by morphology, stratigraphy and current processes on a mire in Kuusamo, Finland. Boreas 14, 287-309.

Söderman, G. (1982) Södra Finlands blocksänkor. Geografisk Tidsskrift 82, 77-81.

Soveri, J. and Varjo, M. (1977) Roudan muodostumisesta ja esiintymisestä Suomessa vuosina 19551975. (Summary: On the formation and occurrence of soil frost in Finland 1955 to 1975.) Publications Water Research Institute, National Board of Waters, Finland 20, 66 p.

Tabuchi, H. and Seppälä, M. (1997) Climate of palsa, pounu area in northernmost Finland. Proceedings of the General Meeting of the Association of Japanese Geographers 51, 52-53.

Tricart, J. (1970) Geomorphology of cold environments. Macmillan and Co Ltd, London. 320 p.

Threlfall, J.L. (1987) The relationship between discharge and suspended sediment in a small nival subarctic catchment. In: V. Gardiner (ed.): International Geomorphology Part 1, 823-841.

Thorn, C.E. (1992) Periglacial geomorphology: What, Where, When? In: John C. Dixon and Athol D. Abrahams (eds.): Periglacial geomorphology. John Wiley \& Sons, Chichester, 1-30.

van Vliet-Lanoë, B., Seppälä, M. and Käyhkö, J. (1993) Dune dynamics and cryoturbation features controlled by Holocene water level change, Hietatievat, Finnish Lapland. Geologie en Mijmbouw 72, 211-224.

Washburn, A.L. (1979) Geocryology: A survey of periglacial processes and environments. Edward Arnold, London, 406 p. 